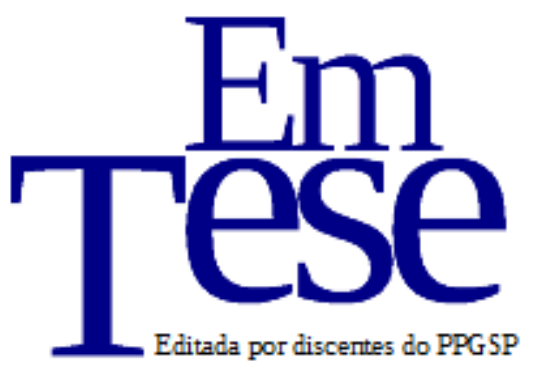

UFSC

PPG SP PROG RAMA DE

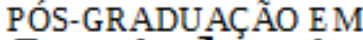

Sociologia

Política

v. 14, n. 1, jan./jun., 2017

\title{
Vaticínios sobre o Golpe de 1964 no pensamento político e social brasileiro
}

\author{
Ricardo Ramos Shiota ${ }^{1}$
}

Resumo: Foi o golpe de Estado de 1964 uma surpresa para os pensadores políticos das esquerdas? Fundamentado na história das ideias, este artigo pretende demonstrar que diversos intelectuais, na conjuntura que levou ao golpe contra o governo de João Goulart, levantaram hipóteses e fizeram vaticínios a respeito da possibilidade de um golpe das classes dominantes, associadas ou não à caserna, o qual viria a impedir o avanço da conquista de direitos sociais e fechar o jogo político democrático no Brasil.

Palavras-chave: Pensamento político e social brasileiro. Conjuntura de 1960 a 1964. Golpe empresarial-militar.

\section{Predictions on the 1964 Coup in Brazilian political and social thinking}

\begin{abstract}
Was the 1964 coup a surprise to the political thinkers of the lefts? Based on the history of ideas, this article argues that many intellectuals in the conjuncture that provoked the coup against João Goulart government, raised hypothesis and made predictions about the possibility of a coup of the ruling classes, associated or not to the casern, that would prevent the advance of the conquest of social rights and close the democratic political game in Brazil.
\end{abstract}

Keywords: Brazilian political and social thinking. Conjuncture from 1960 to 1964. Militarycorporate coup.

\footnotetext{
${ }^{1}$ Doutor em Sociologia pela Universidade Estadual de Campinas. Bolsista Capes/PNPD pelo Programa de PósGraduação em Sociologia Política da Universidade Estadual do Norte Fluminense. E-mail: rrshiota@ gmail.com.
} 


\section{Introdução}

Os fatos políticos ocorridos no final de março e início de abril de 1964 no Brasil têm sido objeto de uma vasta literatura. Ainda hoje o evento histórico tem o significado em disputa pelas forças sociais e pelas correntes historiográficas, uma vez que estamos no terreno da história do tempo presente e permanece a disputa entre memória e história.

Diante destas controvérsias, apoio essas reflexões na obra de René Dreifuss (1981), o qual revelou o caráter de classe social do golpe de 1964 ao designá-lo como golpe "civil-militar" e qualificá-lo como "golpe empresarial-militar". Segundo ele, com base em abundante documentação, o golpe ocorrido em 1964 foi um "movimento", um "projeto" de classe e não um simples Putsch ou quartelada.

Um exame mais cuidadoso desses civis indica que a maioria esmagadora dos principais técnicos em cargos burocráticos deveria (em decorrência de suas fortes ligações industriais e bancárias) ser chamada mais precisamente de empresários, ou, na melhor das hipóteses, de tecno-empresários. (DREIFUSS, 1981. p.417).

Os conspiradores, segundo Dreifuss (1981), iniciaram suas atividades, de modo sistemático, no ano de 1961, após a renúncia de Jânio Quadros à presidência e a conturbada sucessão de João Goulart - que sofreu oposição da Cúpula do Exército e só foi possível devido ao apoio de Brizola e do Terceiro Exército, situado em Porto Alegre. Neste contexto surge o "complexo IPES/IBAD 2", principais centros da articulação da burguesia e dos latifundiários que levou a tomada de assalto do poder de Estado contra as reformas de base $\mathrm{e}^{3}$ em 1964. Além das frações burguesas dominantes, o golpe empresarial-militar teve o apoio de partidos, jornais, sindicatos, federações e confederações patronais, associações civis - com destaque para o Conselho Superior das Classes Produtoras (CONCLAP) -, intelectuais, políticos, da grande maioria da Igreja Católica, extremistas de direita, tradicionalistas com suas frentes políticas reacionárias, além da Escola Superior de Guerra e os militares de direita.

Assim, sem desconsiderar a articulação de grandes interesses capitalistas com apoio geoestratégico do imperialismo estadunidense, Dreifuss (1981) revelou o caráter de classe do golpe de 1964 ao demonstrar que o mesmo não esteve apenas a serviço de um interesse

\footnotetext{
${ }^{2}$ Instituto Brasileiro de Pesquisas e Estudos Sociais; Ação Brasileira de Ação Democrática.

${ }^{3}$ As reformas de base foram concebidas por intelectuais vinculados ao nacionalismo de esquerda e ao reformismo radical. Como projeto político, as reformas de base pretendiam retomar o modelo de desenvolvimento getulista com investimentos em infra-estrutura e ampliação de direitos para os trabalhadores (FERRREIRA, 2007).
} 
econômico-corporativo, mas, sobretudo, a serviço da classe capitalista, liderada pela fração mais associada com o capital estrangeiro ${ }^{4}$.

Ianni (1984) também percebe a ditadura de 1964 como “expressão das lutas de classes em âmbito nacional e internacional" (IANNI, 1984, p.95). Segundo ele, no pré-1964, a burguesia inspirou, orientou, comandou e desestabilizou o governo Goulart através de inúmeras ações, para conter o avanço popular da época. Os militares são a ponta do iceberg, apenas aparência deste processo social. Os militares golpistas representavam os interesses da grande burguesia internacional e dos latifundiários. A ditadura foi uma opção política da grande burguesia, do capital monopolista.

Após o golpe, de acordo com Ianni (1984), a ditadura desenvolveu as forças produtivas e relações sociais de produção capitalistas na cidade e no campo, diversificou a estrutura ocupacional, favoreceu a concentração e a centralização do capital. Através dela, o capital financeiro e monopolista conquistou de vez a sociedade e o Estado; as razões do Estado brasileiro passaram a ser as razões do capital financeiro e monopolista. Com o golpe da grande burguesia, o Estado brasileiro tornou-se gerente de uma vasta fábrica de acumulação: a sociedade brasileira. A ditadura destruiu instituições e direitos democráticos que vinham sendo gestados desde o Estado Novo até a Constituição de 1946. As movimentações populares (eleições, partidos, sindicatos, associações, ligas, debates, comícios, greves, reivindicações e luta por direitos) foram proibidas à força pelo mando da grande burguesia monopolista e financeira. A ditadura iniciada em 1964 resultou da articulação de interesses antipopulares, reacionários, antinacionais para ampliar a exploração dos trabalhadores rurais e urbanos.

Embora as conspirações sistemáticas para a derrubada de João Goulart estejam ligadas à criação do "complexo IPES/IBAD”, no pensamento político-social brasileiro a ideia da necessidade de uma ditadura militar como meio para a instituição da ordem e da disciplina coletiva vem da década de 1920. Juarez Távora ${ }^{5}$ (1928) crítico tanto das elites dirigentes, representantes dos interesses oligárquicos, quanto da possibilidade de um governo proletário, elegia como agentes da mudança as forças armadas, sobretudo, os altos escalões, a verdadeira "escol nacional” capaz de proteger a nação contra os excessos da indisciplina popular e dos governos que vilipendiam as leis e a Constituição.

\footnotetext{
${ }^{4}$ Para comentários sobre o livro de Dreifuss (1981) ver o Dossiê organizado por João Quartim de Moraes e Lígia Osório Silva. Cf. Revista Ideias. Ano 12(2)/13(1). A respeito da recepção do livro de Dreifuss (1981) na historiografia: Cf. Toledo (2004); Melo; Hoeveler (2014).

${ }^{5}$ General egresso das fileiras tenentistas, Juarez Távora participou dos levantes de 1922 no Rio de Janeiro e de 1924 em São Paulo e no Rio Grande do Sul. Atuou na Coluna Miguel Costa-Prestes, na Revolução de 1930 e na fundação do Clube 3 de Outubro. Opôs-se a adesão de Prestes ao marxismo. Mais tarde, filia-se à União Democrática Nacional (UDN), opôs-se aos setores nacionalistas das forças armadas na ocasião do debate sobre o petróleo brasileiro. Em 1952 assume a direção da Escola Superior de Guerra (ESG), após o suicídio de Vargas assume a chefia do Gabinete Militar do governo de Café Filho. Nas eleições de 1955 foi candidato a presidente pela UDN. Em 1962 foi deputado Federal pela Guanabara pelo Partido Democrata Cristão (PDC). Fez oposição a João Goulart e apoiou o golpe empresarial-militar de 1964.
} 
Continuo a crer que nós, militares, podemos e devemos constituir uma força respeitável diante do novo poder que se erigir - qualquer que ele seja. Não nos esqueçamos de que, depois da luta, seremos os verdadeiros baluartes sobre que terá de apoiar-se a ditadura nascente, pois continuaremos a ter em nossas mãos, direta ou indiretamente, toda a tropa que houvermos comandado na revolução (TÁVORA, 1928, p.160-161).

Ademais, sempre as mesmas forças políticas reacionárias, ao longo do interregno democrático, patrocinaram a maioria das tentativas de golpes, com exceção do contragolpe que assegurou a posse de Juscelino Kubitschek à presidência da República. Vargas foi derrubado em 1945 por um golpe militar e, em 1950, ao voltar ao poder, questionado por conservadores e liberais. Em 1954, estas mesmas forças, derrubaram Getúlio Vargas que preferiu o suicídio a entregá-las o poder de Estado. Em 1955, essas forças tentaram, sem sucesso, impedir a posse de JK. Elas atuaram também em 1961 para impedir a posse de João Goulart, obtiveram com certo êxito, na medida em que impuseram o regime parlamentarista. Assim,

\begin{abstract}
é possível sustentar que o Golpe de 1964 constituiu o coroamento das iniciativas de setores políticos e militares que, desde 1950, se opunham, de forma sistemática, à consolidação e ao alargamento da democracia política no Brasil; no curto período do mandato presidencialista de Goulart, estes setores passam a questionar radicalmente a realização das chamadas reformas de base e de medidas que afetavam o capital estrangeiro. Na visão dos protagonistas do golpe, a crescente mobilização política e o avanço da consciência ideológica dos setores populares e dos trabalhadores, que se acentuava na conjuntura, poderiam implicar o questionamento do sistema político e da ordem econômico e social que, a rigor, deveriam permanecer sob o estrito controle e domínio das classes possuidoras e proprietárias (TOLEDO, 2004, p.42).
\end{abstract}

Muitos trabalhos desqualificaram o pensamento político-social das esquerdas do pré1964, em sintonia com o contexto específico da ditadura empresarial militar, das décadas de 1970 e 1980 e foram produzidos por intelectuais vinculados à Universidade de São Paulo. Isso fez com que o pensamento político elaborado na conjuntura do golpe se tornasse um ilustre desconhecido. No âmbito desta historiografia, destacam-se os textos e livros de Francisco de Oliveira (1972), Caio Navarro Toledo (1977), Maria Sylvia Carvalho Franco (1978) e Marilena Chauí (1983). Tornou-se senso comum acadêmico, nas décadas de 1970 e 1980, a crença de que o golpe de 1964 teria sido uma surpresa para as esquerdas, devido à compreensão teórica equivocada que elaboraram sobre o país. Conforme disse Emília Viotti (1975):

[...] muitos analistas dos anos 50 [...] esperavam que a burguesia brasileira promovesse uma revolução liberal, democrática e nacionalista. Ao contrário, o Brasil ganhou um regime autoritário que institucionalizou mecanismos para suprimir qualquer oposição real e abriu o país aos investimentos estrangeiros. [...] Depois de 1964, tornou-se evidente que as elites brasileiras não só eram capazes de usar o aparato do Estado em seu benefício comum. Face à nova situação, sociólogos e cientistas políticos decidiram que o modelo dualista era incorreto. A história surpreendeu-os. Tomou uma direção inesperada. Eles tiveram de correr para alcançar a História e isto era ainda mais imperativo, porque alguns deles esperavam guiar a História e a História os deixou para trás. (VIOTTI, 1978, p.178) 
Deste modo, em vista de nuançar este debate, o objetivo do artigo em tela é apresentar as visões gestadas pelas esquerdas no pré-1964 a propósito da possibilidade de um golpe a ser desferido pelas forças conservadoras e liberais. Os intelectuais de esquerda foram pegos de surpresa pelo golpe empresarial-militar de 1964? Eles "tiveram de correr para alcançar a História"? O golpe foi um "raio em céu azul" para os pensadores de esquerda daquela conjuntura?

A hipótese é que houve sim uma consciência a respeito de um possível golpe, presente nos vaticínios e prognósticos desenvolvidos pelos pensadores das esquerdas. Intelectuais que tanto eram favoráveis às reformas de base, quanto os contrários meditaram sobre o iminente golpe. Era comum a publicação pelos jornais de artigos de personas como Carlos Lacerda que defendiam abertamente a intervenção militar na política brasileira. Essa possibilidade de um golpe liberal conservador não estava excluída do horizonte dos atores políticos, sobretudo, porque tais eventos são recorrentes na história política republicana (SODRÉ, 1992).

Para responder as questões e demonstrar essa hipótese, fundamento-me na perspectiva da história das ideias. Segundo Mark Bevir (2008) a história das ideias estuda os significados de enunciados de uma perspectiva histórica, considerando as crenças como intenções fracas. Ocupase do modo pelo qual um autor ou vários autores refletem sobre os dados históricos e não os dados históricos por si mesmos.

Por pensadores das esquerdas ou de esquerda, refiro-me aos intelectuais que tiveram destacado papel no fomento da cultura política popular daqueles idos, em torno da luta pelas reformas de base ou em defesa da revolução brasileira socialista. O conceito de esquerda diz respeito à questão ideológica. Depende da referência às situações históricas concretas e sempre envolve "os representantes dos interesses populares, portadores de ideias avançadas, democráticas e socialistas" (MORAES, 2005, p.28). É um conceito que alude à própria orientação dos agentes no processo histórico, serve para caracterizar oposição de interesses dentro da sociedade de classes no tempo e no espaço. Deste modo, pode variar em cada época histórica.

Nesse sentido, concordo com Daniel Aarão Reis Filho (1997) quando afirma que: "enquanto a historiografia de esquerda não assumir a tradição trabalhista como uma vertente de esquerda, ela estará decisivamente empobrecendo a reflexão sobre a esquerda brasileira, ela estará mutilando a história da esquerda brasileira" (REIS, 1997, p.23). Os pensadores das esquerdas que tratamos neste artigo tiveram seus direitos políticos cassados e foram perseguidos politicamente logo depois do golpe empresarial-militar: democratas, trabalhistas, nacionalistas (de esquerda), socialistas e comunistas (stalinistas, trotskistas, maoístas etc.). 
$\mathrm{O}$ artigo está organizado em quatro partes. Na primeira, em linhas gerais, reconstruo o contexto de enunciação. Na segunda parte, demonstro as visões do golpe de 1964 nos intelectuais favoráveis às reformas de base. $\mathrm{Na}$ terceira, apresento vaticínios dos intelectuais contrários a essas reformas. Por fim, teço as considerações finais.

\section{O Brasil: um país que ia dar certo}

Entre 1945 e 1964 a sociedade brasileira atinge um período novo, o primeiro democrático na história da República, ainda que possa ser caracterizado como uma democracia restrita. Tratase de um interregno no qual os representantes de forças sociais com tendências democratizantes e progressistas puderam tornar públicas expectativas, demandas e ideias para a construção nacional.

No rico interlúdio de 1945 a 1964 tiveram origem diversos movimentos culturais e artísticos, assim como movimentos de arte engajada, entendendo por isso uma estética plural, ideologicamente eclética, comprometida com causas públicas e avançadas. Período de renovação estética, temática e diferenciação das esferas da cultura; período da bossa nova, de renovação da música popular brasileira, da poesia concretista, da arquitetura; período do teatro engajado, do cinema novo, dos Centros Populares de Cultura ligados à União Nacional dos Estudantes, das campanhas de alfabetização inspiradas no método Paulo Freire (NAPOLITANO, 2007).

Nesse período de quinze anos entre a posse de Vargas e a derrubada de Goulart, o país viveu numa encruzilhada: seguir um caminho independente e provavelmente democrático ou continuar subordinado ao império norteamericano com ou sem democracia [...]. O clima geral era de esperança na construção de um país melhor, mais desenvolvido, mais igualitário, mais democrático. (MIGLIOLI, 2005, p.62).

Renovações culturais significativas se exprimiram também através de diversas instituições intelectuais e políticas, as quais ou foram destruídas ou sofreram intervenções através dos IPM's (Inquérito Policial Militar) após 1964. Nesse sentido, são representativos a Assessoria Econômica da Presidência da República de Vargas, a Comissão Econômica para a América Latina (Cepal), o Instituto Superior de Estudos brasileiros (ISEB), o Partido Comunista Brasileiro (PCB), a Cadeira de Sociologia I da USP, o Centro de Estudos Sociais, o Centro Brasileiro de Pesquisas Educacionais (CBPE), o Centro Latino-Americano de Pesquisas em Ciências Sociais (CLAPCS), além de outras instituições e as diversas revistas do período. Expressões de um movimento de conhecimento de si da sociedade brasileira sob a ótica de representantes de forças avançadas. 
Ocorre, então, a emergência de novas forças sociais e novos atores políticos, assim como intensificam as mobilizações sociais. Não obstante "o fato de forças renovadoras irromperem no horizonte político não significa, é claro, o desaparecimento dos setores sociais que garantiam o status quo e também das ideias que sustentavam a visão que apoiava seu desempenho político" (BASTOS, 2008, p.28). Em oposição às ideias nacionalistas de esquerda, havia o agrarismo, o liberalismo, o projeto de capitalismo interdependente da Escola Superior de Guerra (ESG).

\begin{abstract}
Neste período de nossa história política, inúmeros projetos econômicos, sociais e culturais foram formulados e internamente debatidos; nele estiveram envolvidos partidos e frentes partidárias, movimentos sociais urbanos e rurais, sindicatos de trabalhadores, entidades culturais e de artistas, universidades, movimento estudantil, editoras, revistas etc. Essa efervescência cultural era interpretada pelos setores conservadores de forma preocupante; a direita civil e militar alardeava a quatro ventos o "crescimento da baderna política" e da "subversão" da ordem econômica e política [...] o Brasil começava a ficar 'irreconhecidamente inteligente' (TOLEDO, 2005, p.9).
\end{abstract}

Ademais, o anticomunismo pregado pela ESG era usado como meio de aproximação e de pressão aos EUA, no sentido da redefinição das relações deste com o Brasil, reivindicando iniciativas similares ao Plano Marshall (DEBERT, 1989). Serviu como pretexto usado pelos EUA para impedir que o Brasil se transformasse em potência industrial, obscureceu o caráter nacionalista do movimento em torno de João Goulart, contribuiu para ofuscar os espíritos e "confundir" a alta oficialidade das forças armadas (BANDEIRA, 2009). A ideologia raivosa do anticomunismo contribuiu para a resistência às mudanças sociais, para legitimar a cassação do PCB e do mandato de seus membros em 1947. Serviu também para justificar dois golpes de Estado: em 1937 e em 1964.

A despeito da reação, o início dos anos 1960 era uma época de mudanças, que empolgava o Brasil e a América Latina.

O Papa João XXIII reorientava a igreja, Kruchov reformulava a política interna e externa da União Soviética e John Kennedy ainda inspirava, em alguns setores, esperanças nos Estados Unidos. A Revolução Cubana, implantando uma República socialista a 90 milhas dos Estados Unidos, revigorou o sentimento antiimperialista e o espírito de lua de todos os povos da América Latina. O Brasil também sofreu o impacto, exacerbando-se o conflito de classes e a crise nacional que gestava em função do surto industrial da década de 1950 (BANDEIRA, 1985, p.32).

A contradição da época, na crise de 1961-1964, deu-se "entre o poder político, cada vez mais influenciado e orientado por forças de base popular, e o poder econômico, cada vez mais determinado pelos interesses da grande burguesia monopolista estrangeira e nacional" (IANNI, 1984, p.107). Conforme um analista contemporâneo, as forças populares reclamavam urgência nas reformas de base, compreendiam: "estudantes", "operários", "camponeses", "bancários", “comerciários", "sargentos", "soldados" etc. (MORAIS, 1965). 
É neste contexto de enunciação, entre 1960 e 1963, que alguns pensadores políticos e militantes de esquerda exprimiram uma consciência a respeito da possibilidade objetiva de que um golpe contrarrevolucionário pudesse ser mobilizado pelas classes dominantes - com ou sem apoio da caserna -, para conservar o que, aos olhos deles, existia de pior e precisava ser suplantado no Brasil. São eles: Álvaro Vieira Pinto (1960a; 1960b), Wanderley Guilherme dos Santos (1962), Nelson Werneck Sodré (1962), Celso Furtado (1962), Guerreiro Ramos (1961, 1963), Franklin de Oliveira (1962), Bolívar Costa (1962) e Moniz Bandeira (1962). Para facilitar a apresentação, a exposição foi organizada com base no posicionamento destes autores no tocante às reformas de base; naqueles idos palavra-chave, conceito fundamental da linguagem das forças de esquerda, conceito usado pelos agentes ainda que a intenção fosse questioná-lo.

\section{Reformas de base e previsão do golpe de 1964}

O primeiro autor a vaticinar e expor consciência da possibilidade de um golpe foi Álvaro Vieira Pinto ${ }^{6}(1960)$. Ao considerar a derrota das reivindicações populares por direitos políticos e por reformas de base, o autor previa o brutal esmagamento da incipiente consciência crítica das massas.

Valendo-se de uma compreensão particular sobre as reformas de base, Pinto (1960a; 1960b) as defendia, fundamentalmente, como um meio de promover a elevação do nível de vida e a maior participação política das massas nos processos decisórios, a ativa presença do Estadodemocrático na vida da nação, a posse dos controles, dos mecanismos decisórios da economia nacional. Para ele, as reformas de base também envolviam a estatização de empresas estrangeiras, o repúdio ao capital estrangeiro, pois, "significa sempre trabalho para outro", por isso, não seriam fáceis de serem aprovadas.

Para Vieira Pinto (1960) o golpe das forças conservadoras e liberais seria uma iniciativa da consciência ingênua, a "consciência dominante" de seu tempo, que abrange as concepções, as teses, as crenças, os preconceitos, os moralismos, as fórmulas anti-históricas. Muitas delas presentes, de modo sistemático, no pensamento político-social brasileiro ligado ao catolicismo, ao tenentismo, ao integralismo, ao liberalismo, ao conservadorismo e ao reacionarismo. Há um pressuposto interessante nesta categoria que consiste em reconhecer a conexão existente entre os

\footnotetext{
${ }^{6}$ Álvaro Vieira Pinto (1909-1987), como muitos intelectuais, ao longo de seu itinerário transformou radicalmente suas crenças e posicionamentos políticos. Na juventude, aos 23 anos formou-se em medicina e aos 25 fizera parte da Ação Integralista Brasileira (AIB), organização de inspiração fascista, liderada por Plínio Salgado. A paixão pela filosofia, porém, redimensionou as preocupações de Vieira Pinto, que logo se tornou professor de lógica matemática na Universidade do Distrito Federal (UDF). Em 1955, a convite de Roland Corbisier, Vieira Pinto, aos 46 anos, tornou-se chefe do Departamento de Filosofia do recém-criado Instituto Superior de Estudos Brasileiros (ISEB), organizado no âmbito do Ministério da Educação e Cultura. Em 1962, Vieira Pinto assumiu a direção executiva do ISEB, em um momento de crise financeira e acirrada campanha difamatória movida pela imprensa conservadora, tendo à frente o jornal O Globo. Cf. Cortês (2003).
} 
postulados da consciência ingênua e certas filosofias sociais caducas do ponto de vista do projeto de superação do subdesenvolvimento. Trata-se da retórica da intransigência brasileira no período, o pensamento das forças sociais e políticas golpistas, majoritariamente, forças da contrarrevolução.

O filósofo isebiano reconhecia a possibilidade objetiva do golpe das classes dominantes articuladas com os generais e as forças do imperialismo. No ano de 1960 afirma que, caso o golpe contrarrevolucionário ocorresse, as forças sociais e políticas conservadoras presentes na sociedade brasileira renunciariam à virtualidade de o país ser uma grande potência mediante rápido e iminente desenvolvimento, no sentido substantivo, para se contentar com o projeto heterônomo de nação subimperialista e polo da reação na América Latina.

Tal incidente histórico não significa verdadeiro retrocesso no curso do desenvolvimento, mas o momentâneo revigoramento de forças reacionárias existentes no ambiente social, que procuram fortalecer-se em vista da íntima insegurança que sentem em sua própria situação. Só teria sentido falar em triunfo se houvesse a entrada de novas forças originais no cenário social. Tratando-se, porém, de simples reagrupação de potências representativas do que de mais arcaico existe em nossa realidade, não se deve interpretar como sucesso das vitórias que venham a ter, mas como inevitável coleio do curso histórico (VIEIRA PINTO, 1962b, p.109).

O possível golpe de Estado da classe dominante no Brasil imporia uma nova política de dominação externa e interna, pressagiava o filósofo isebiano em 1960. Com o sucesso da contrarrevolução, dizia ele, os Estados Unidos iriam transferir fábricas para o Brasil, área estratégica para a sobrevivência mundial do capitalismo, naquele contexto. O país, hospedeiro de investimentos e capitais norte-americanos, passaria a se especializar no fornecimento de recursos naturais, mão-de-obra barata, transferência de lucros e pagamento de juros. A contrarrevolução faria do Brasil um aparelho intermediário para exploração do trabalho das massas e nações sulamericanas pelo imperialismo norte-americano. Mais tarde, Ruy Mauro Marini desenvolve o conceito de subimperialismo, cujo embrião está presente nesta obra monumental de Vieira Pinto.

Já Wanderley Guilherme dos $\operatorname{Santos}^{7}$ (1962), cujo livro teve mais recepção, também expressou essa consciência da possibilidade de um iminente golpe das forças liberais e conservadoras. Todavia, acreditava que a opção era entre alterar ou não a estrutura capitalista do Brasil. E não entre capitalismo e socialismo. Reconhecia a existência de um avanço real do movimento popular brasileiro por meio das reformas de base, defendidas como reforma agrária radical, reforma urbana, universitária, participação dos trabalhadores nos lucros, regulamentação do direito de greve, barreira às exportações de riqueza do país, controle do capital estrangeiro. As dificuldades do país derivavam do fato de a economia capitalista ser dominada pelo

\footnotetext{
${ }^{7}$ Wanderley Guilherme dos Santos (1935 - ) cientista político brasileiro, autor de vários livros e artigos na área de Ciências Sociais.
} 
imperialismo e essa condição seria mantida com a possibilidade objetiva do golpe de Estado das forças liberais e conservadoras.

A seu ver, a ameaça de golpe não é recente na sociedade brasileira, mas manifesta-se toda vez que o movimento popular avança, como em 1953 durante a luta em torno da Petrobrás e, em 1961, com a luta pela legalidade e maior ganho de poder político pelas forças nacionalistas. Desta vez, alertava no ano de 1962, um golpe antipopular interessado na imposição de um governo forte estava sendo gestado. Embora não tivesse certeza de que se trataria de um golpe militar, Santos (1962) não ignorava essa hipótese. Critica o golpe e defende que o mesmo pressupõe o fato de a minoria dirigente rasgar suas próprias leis, alterar as regras do jogo político criado por ela mesma. Para ele, o golpe seria desferido contra os interesses populares defendidos pelos trabalhadores urbanos, rurais e estudantes, cuja luta estava fazendo avançar direitos sociais. Seria um movimento da minoria contra a maioria do povo. O acúmulo de poder conquistado pelas forças populares era a justificativa para o golpe de direita e contrarrevolucionário, o qual estava sendo preparado pelas classes dominantes brasileiras em associação com o imperialismo.

A ditadura militar, conforme o presságio de Wanderley Guilherme dos Santos (1962), aconteceria como operação política e não como operação militar. Sob esta condição política, a ditadura militar serviria aos interesses de uma minoria. Conforme ele, uma coisa é o papel desempenhado pela corporação militar, outra o golpe militar, que depende da coesão relativa dos membros das forças armadas e da necessidade social da classe dominante para implantá-lo. A ditadura, se implantada, buscaria "retirar do povo o direito de discutir assuntos públicos isto é, que lhe dizem respeito" (SANTOS, 1962, p.68), impediria o povo de discutir seus próprios problemas, previa o autor. Em suma, a ditadura viria para estabelecer um fim à participação política popular, impor pelas armas o princípio político de estabelecer que "as soluções para os problemas que afetam o Povo e a Nação não devem ser resolvidos mediante lutas sociais" (Santos, 1962, p.69). Com a ditadura, as lutas sociais seriam proibidas e duramente reprimidas. Sempre que as classes dominantes declaram as lutas sociais ilegais, o povo, a plebe, sai perdendo. As minorias privilegiadas sabem perfeitamente que só através das lutas sociais as massas trabalhadoras podem se defender e avançar na conquista de direitos sociais.

A consciência do golpe aparece também em Nelson Werneck Sodré ${ }^{8}$ (1962). Para ele, o golpe militar era uma alternativa conveniente para os inimigos das reformas de base e do avanço

\footnotetext{
${ }^{8}$ Nelson Werneck Sodré (1911-1999) militar, historiador e crítico literário de orientação marxista e nacionalista, membro do PCB desde a década de 1940. Fez carreira militar e somou com as forças políticas nacionalistas e comunistas no interior do exército, participando como diretor cultural do Clube Militar na gestão do general Newton Estillac Leal, a qual atuou na Campanha do Petróleo é Nosso, defendeu a tese do monopólio estatal, engajamento que custou a Sodré transferências para bases do Exército nos rincões do Brasil. Também foi professor de história militar da Escola de Comando e Estado Maior e professor do Instituto Superior de Estudos Brasileiros (ISEB). Colaborou como crítico literário para os jornais Correio Paulistano e Última Hora. Foi professor visitante da Universidade de Brasília (UnB).
} 
da conquista de direitos sociais. Favorável às reformas de base, afirma que deveriam transformar a estrutura nacional, no sentido do capitalismo independente. $\mathrm{O}$ fundamental, conforme o projeto político defendido pelo autor é a supressão do latifúndio e do imperialismo da economia brasileira, a ampliação do regime democrático e solução nacionalista (de esquerda) dos problemas de exploração de nossas riquezas. O regime democrático permite o avanço das forças populares, como tornou possível a reivindicação civil por reformas de base. "O clima democrático asfixia progressivamente as forças reacionárias, que se incompatibilizam com ele, pedem imploram um governo de exceção, um golpe salvador, uma poderosa tranca na porta para impedir as forças do progresso" (SODRÉ, 1962, p.35).

Porém, latifundiários e burgueses, ao serem ameaçados, se preciso fosse, apelariam para "guerra civil, pois [...] não recuarão ante ato algum" contrário aos seus interesses. Em país onde o regime democrático era novidade e a questão social caso de polícia ou de exército, o avanço popular através da conquista de direitos, ao longo do interregno democrático e, sobretudo, do governo Goulart, deixava as classes dominantes e seus generais reacionários doutrinados pelo Império em estado de alerta. "Resta-lhes, em casos tais, pelos seus agentes, declarar interrompido o processo democrático, inválida a vontade popular, quebrados os dispositivos constitucionais" (SODRÉ, 1962, p.56). Com isso, arremata esse autor: "as classes dominantes, no Brasil, assumem cada vez mais o papel de forças subversivas - elas sim - porque desrespeitam a lei, sempre que o cumprimento da lei lhes fere ou ameaça os interesses" (SODRÉ, 1962, p.60).

Celso Furtado $^{9}$ (1962) também discerniu a possibilidade de recusa pelas classes dominantes do projeto das reformas de base e do governo de Goulart. Para ele o subdesenvolvimento era uma condição histórica resultante do desenvolvimento capitalista. Neste tipo de sociedade, em razão de "obstáculos estruturais específicos", as reformas de base são fundamentais, assim como a intervenção do Estado na economia. A intervenção do poder executivo, porém, depende também do aval do poder legislativo, onde as forças de esquerdas não dispunham maioria representativa. Assim, compreendia as reformas de base como processo de natureza política e não de natureza técnica, o "tratamento de questões qualitativas (técnicas e políticas)" (FURTADO, 1962, p.74). O planejamento é menos um problema racional do que de

\footnotetext{
${ }^{9}$ Celso Furtado (1920-1997) economista, cientista social, "homem de ação", professor universitário e intérprete do Brasil. Doutorou-se em Economia pela Universidade de Paris. Integrou a Comissão Econômica para a América Latina (Cepal). Foi nomeado pelo presidente Juscelino Kubitscheck interventor do Grupo de Trabalho para o Desenvolvimento do Nordeste e participou da criação e presidiu a Superintendência do Desenvolvimento do Nordeste (Sudene), agência voltada para o planejamento e coordenação de programas socioeconômicos para a região. Em 1962 foi nomeado por João Goulart para ocupar o Ministério do Planejamento, onde elaborou, junto a San Tiago Dantas, o Plano Trienal de Desenvolvimento Econômico e Social. Sem apoio político, o fracasso do plano para estabilizar e fazer a economia voltar a crescer implicou a saída de Furtado do ministério em junho de 1963, quando retoma suas atividades na Sudene até o golpe empresarial-militar.
} 
natureza política, conforme as regras do jogo político existentes. As reformas de base tinham que respeitar também os limites constitucionais.

Furtado defende um Estado interventor, democrático e de bem-estar social. Tratava-se de “conciliar o máximo de bem-estar econômico para a maioria e uma rápida melhoria nas condições de vida do povo com um sistema político baseado no máximo de liberdade pessoal, inclusive no campo da organização da produção" (FURTADO, 1962, p.74). Para ele, a origem dos problemas brasileiros é de natureza econômica. "Não é possível educar o homem sem antes lhe matar a fome" (FURTADO, 1962, p. 91), afirma Furtado polemizando com a crença da educação como panacéia dos problemas brasileiros.

Questiona a contrarrevolução e tem a correta percepção da possibilidade da reação, de um golpe ditatorial de direita no Brasil desferido pelas forças conservadoras e liberais, naqueles idos históricos.

\footnotetext{
Para evitar um retrocesso social não basta desejá-lo: é necessário criar condições objetivas de caráter preventivo. O retrocesso na organização político-social não virá ao acaso, e sim como reflexo do pânico de certos grupos privilegiados em face da pressão social crescente. Não permitindo as rígidas estruturas adaptações gradativas, a maré montante das pressões tenderá a criar situações pré-cataclísmicas. Nessas situações é que os grupos dominantes são tomados de pânico e se lançam às soluções de emergência e golpes preventivos. Fossem as modificações progressivas ou gradativas, e o sistema político social resistiria (FURTADO, 1962, p.31).
}

Ao defender uma mudança gradativa das estruturas econômicas e sociais como forma de evitar o golpe, Furtado (1962) não imaginava a intensidade da resistência às mudanças sociais progressivas das classes dominantes brasileiras. Porém, apontava que o golpe seria produto da reação de "certos grupos privilegiados" e não obra do acaso.

Os documentos do PCB na conjuntura que antecedeu o golpe revelam adesão do Partido as reformas de base e manifestam a consciência da possibilidade de um golpe a ser desferido pelas forças na conjuntura do golpe de 1964.

O Partido Comunista do Brasil, conforme Segatto (2008), teve uma trajetória histórica "errática e complexa", ao longo de 1945 a 1964. Legalizado com o fím do Estado Novo elegeu 14 deputados federais e um senador nas eleições de 1945 para a Constituinte de 1946. Banido do jogo político, entre 1948 a 1954, o partidão deu uma guinada a uma concepção golpista e sectária do processo político, que levou ao alinhamento com o Kominform, agência de informação dos PC's, stalinista e isolacionitsa. Com a reação popular ao suicídio de Getúlio Vargas, em 1954, e as revelações de Nikita Kruschev no XX Congresso do PCU, em 1956, acerca dos crimes de Stalin, o partido vive um momento de crítica interna, crise, renovação e busca de uma nova política. As mudanças surgem na Declaração de Março de 1958 e na Resolução do V Congresso de 1960. A "nova política" do partido voltava-se para o desencadeamento da "revolução brasileira" através de soluções positivas e reformas de base. 
Entre 1958 e 1964, conforme Brandão (1999), o programa político do PCB orientava-se para soluções específicas para problemas específicos por meio do estabelecimento de objetivos intermediários, exame realista da correlação de forças e metas realistas, capazes de guiar o conjunto de forças que se reconheciam como parte da frente nacionalista e democrática. Ele caracterizou-se pelo compromisso, ainda que tácito, com a democracia ao recusar reduzir a política à guerra e pela percepção confusa de que o país estava condenado ao capitalismo.

Encontrei passagens textuais nas quais está manifesta e aventada a hipótese do golpe. Uma delas, no documento Os comunistas e a situação da política nacional, de julho de 1963, está expresso:

Os reacionários e entreguistas tudo fazem para criar o clima necessário ao golpe de direita e à implantação de uma ditadura a serviço do imperialismo norte-americano e do latifúndio. As forças patrióticas devem estar vigilantes e prontas a responder a qualquer tentativa de golpe, através da ação das massas populares (CARONE, 1982, p.260).

Outro analista, Guerreiro Ramos ${ }^{10}$ (1961) também foi mais um pensador político das esquerdas que também vaticinou com acerto histórico e defendeu as reformas de base. Ramos (1961), questiona o janguismo por fazer apelo à política tradicional - ao paternalismo e à política de nomeações. Com grande acerto histórico afirma:

\begin{abstract}
Se é certo que o Sr. João Goulart, neste momento, é dos poucos homens desse país a quem as massas obedeceriam, se se dispusesse a uma jogada revolucionária, tudo indica encontrar-se em uma encruzilhada na sua carreira. Ou renova os seus processos de atuação política, abandona o sistema de manipulações de cúpula partidária e sindical e empreende trabalho de base com o objetivo de nuclear em todo o país, mediante o PTB, efetivas forças populares, à maneira do que, por exemplo, faz Julião com as ligas camponesas, ou será superado pelos acontecimentos e verá declinar sua influência (RAMOS, 1961, p. 92).
\end{abstract}

Guerreiro Ramos rompeu com as concepções sobre a revolução brasileira que defendia durante sua participação no IBESP e no ISEB na conjuntura do golpe. Ao deixar o ISEB em 1958, abandonou também a fé no desenvolvimentismo e na burguesia nacional, torna-se socialista convicto, porém sem partilhar do credo do marxismo-leninismo. Neste contexto defende as reformas de base, porém, para serem realizadas deviam ser precedidas por uma

\footnotetext{
${ }^{10}$ Alberto Guerreiro Ramos (1915-1982) na mocidade vinculou-se ao integralismo na Bahia, rompendo com o mesmo após se mudar para o Rio de Janeiro em 1939. Em seguida, forma-se em Ciências Sociais no ano de 1942 e, em Direito, no ano de 1944 pela Universidade do Brasil. Fez parte do Departamento Nacional da Criança e do Departamento de Administração do Serviço Público, instituições criadas por Getúlio Vargas. Associou-se ao Teatro Experimental do Negro, criado por Abdias do Nascimento. Entre 1951 e 1954, Guerreiro Ramos participou da Assessoria Econômica da Casa Civil do segundo governo de Getúlio Vargas. Participou do Grupo de Itatiaia, do IBESP (Instituto Brasileiro de Economia, Sociologia e Política), e do primeiro Iseb (Instituto Superior de Estudos Brasileiros). Depois de 1958, Guerreiro Ramos milita no PTB, pelo qual lançou sua candidatura a deputado federal nas eleições de 1962. Com expressiva votação, Guerreiro Ramos tornou-se suplente de Leonel Brizola e assumiu a cadeira no Congresso no ano de 1963. Porém, com o golpe empresarial-militar e o Ato Institucional n ${ }^{\circ}$, Guerreiro Ramos teve seu mandato cassado e perdeu seus direitos políticos. Em 1966, Guerreiro Ramos se exila nos EUA, onde fez carreira como professor universitário na University of Southern California (USC).
} 
reforma política democrática, capaz de tornar os partidos políticos mais representativos e instituir o voto ideológico. "Nossos problemas econômicos do momento decorrem menos da falta de recursos do que da distribuição dos recursos já existentes, desde que subordinada à critérios públicos" (Ramos, 1961, p.94). Os problemas brasileiros são essencialmente políticos: falta de princípios ideológicos, fortes objetivos personalísticos, ausência de um dispositivo partidário que, por idoneidade ideológica, seja capaz de arregimentar as massas, cujo poder forneceria as bases para promover reformas de envergadura.

Ramos (1963) em outro livro, mais cético e pessimista, aponta o grande nível de internacionalização da economia brasileira como um fator favorável à atuação de forças políticas externas no processo da revolução brasileira. Denuncia a mobilização para a contrarrevolução de instituto de pesquisas e estudos (IBAD/IPES), jornais, revistas, editoras, estações de rádio e televisão, financiados pela extrema direita da classe dominante e com recursos externos. Ele identifica uma crise da cultura política das esquerdas que, supostamente, estaria fora do lugar, não enraizadas na "realidade brasileira". Cético, Guerreiro Ramos afirmava a existência de condições objetivas para a revolução e lamentava a carência de condições subjetivas.

A atual crise brasileira, malgrado os seus efeitos deteriorantes no domínio econômico, financeiro e social, até agora não gerou polarizações agudas que permitam surgir um movimento revolucionário adulto do ponto de vista da organização, da ideologia e da liderança (RAMOS, 1963, p.190).

A revolução brasileira é designada como “jornada de otários”, pois as condições objetivas para o processo estariam dadas. O diagnóstico aponta a perda pela minoria dominante (o governo Goulart) do controle da situação econômica e política. Acentuada consciência coletiva da caducidade do sistema institucional vigente ou perda do consenso, ineficiência do aparelho governamental no tocante aos negócios ordinários e especialmente à defesa da autoridade e do regime. $\mathrm{O}$ autor identifica inclusive dualidade de poder, presente nas forças armadas, uma vez que o aparelho de segurança nacional reagia de modo lerdo e insatisfatório, com tolerância às manifestações contra status quo. Aponta ainda uma divisão entre os círculos governamentais, a deserção dos intelectuais e a presença de espontâneos movimentos de massa e pouca organização revolucionária. Ao mesmo tempo, ponderava.

Ocorre, entre nós, que os círculos conservadores não estão suficientemente minados em suas bases e destituídos de meios para não poderem repelir, com eficácia, ameaça grave aos seus interesses essenciais e, por outro lado, não existe liderança capacitada para fazer da revolução um fato nacional, manifestação coletiva do povo brasileiro, configuradora de novo poder. A revolução, no Brasil de hoje, é ideia-força, não é processo político orgânico. Por isso, os revolucionários podem ter êxito como personalidades isoladas, mas não como expressão de um comando da revolução, nacionalmente unificado (RAMOS, 1963, p. 191). 
Cético ele reconhecia o poder econômico das classes dominantes e a presença de "forças externas" na política brasileira, assim como e a tendência histórica de as classes dominantes conservarem o poder por meio da circulação de elites, da revolução assumida e da derrocada. O ceticismo de Guerreiro Ramos tornou-se realidade histórica, usando sua linguagem, podemos admitir que com, o golpe de abril de 1964, as classes dominantes brasileiras, apoiadas por forças externas, recompuseram o poder ou dominação e imposição de controle interno usando a derrocada.

\section{Críticos das reformas de base e vaticínios do golpe de 1964}

Em livro publicado no ano de 1962 - quando o regime parlamentarista fora imposto mediante uma tentativa de golpe -, Franklin de Oliveira ${ }^{11}$ (1962) alertava os leitores a respeito da possibilidade de um novo golpe das forças liberais e conservadoras com vistas a neutralizar a ascensão ao poder das forças políticas de origem popular. Apontava a existência de um processo revolucionário em curso no Brasil desde 1930, o qual se exacerbou após a renúncia do presidente Jânio Quadros e a combatida posse do vice-presidente João Goulart pelas forças da contrarrevolução. Dizia ele, "estamos, ao que tudo indica à beira da solução ditatorial militar, porque a ditadura disfarçada do governo de união nacional torna-se cada vez mais ineficiente. Esse parece o desenvolvimento natural que terá o Brasil nos próximos meses ou anos" (OLIVEIRA, 1962, p.26). Além disso, acrescentava:

os homens que ocupam o poder, as classes dominantes não parecem dispostos a admitir o avanço das massas populares. Apegados aos interesses de classe e temerosos da nova sociedade que se esboça, recorrerão certamente à violência, como fizeram em outras ocasiões. Recorrerão ao golpismo e à ditadura. (OLIVEIRA, 1962, p.122).

Oliveira defendia a remoção de todos os fatores geradores das desigualdades sociais brasileiras por meio de radical mudança na estrutura do Estado brasileiro, capaz de promover libertação nacional, emancipação econômica, pressupostos das demais reformas. Contra as reformas de base, defendia a necessidade de um poder político popular, revolucionário e socialista. Pois, as reformas de base não atingiriam o cerne da questão social. Ao serem realizadas pelos representantes políticos das classes dominantes, converteriam-se em agentes

\footnotetext{
11 Jose Ribamar de Oliveira Franklin da Costa (1916-2000) foi jornalista, critico literário e homem de Estado. Nascido em São Luís, migrou para o Rio de Janeiro em 1938, onde se destacou na imprensa carioca. Participou do Congresso Brasileiro de Escritores como delegado do Distrito Federal, na cidade de São Paulo em 1945, evento organizado pela Associação Brasileira de Escritores. Em 1960, transferiu-se para Porto Alegre, participando do governo Leonel Brizola (1958-1961) como secretário-geral do Conselho de Desenvolvimento do Rio Grande do Sul. Atuou como delegado desse estado junto ao Banco de Desenvolvimento Regional do Extremo Sul. Exerceu importantes funções administrativas na Petrobras entre 1962 e 1964, quando teve seus direitos políticos suspensos pelo Ato Institucional no 1 (9/4/1964). Depois do golpe, retornou ao jornalismo e às atividades literárias.
} 
entorpecedores da revolução. "Só a revolução social aciona as reformas reais" (Oliveira, 1962, p.62). A revolução resultaria de um aproveitamento das liberdades democráticas, da organização e mobilização popular como meio de debilitar poder dominante, de uma tática que combinaria pressão de cúpula e pressão de base contra as instituições burguesas e seus agentes. Além da luta libertária no âmbito social, era preciso conquistar maioria parlamentar, para retirar o Parlamento à condição de ser órgão burguês e convertê-lo em instrumento do desenvolvimento pacífico da revolução.

Outro analista, Bolívar Costa ${ }^{12}$ (1962), também questiona as reformas de base, em razão de serem promovidas por iniciativa das classes dominantes. A apropriação da categoria reformas de base pelo governo de João Goulart obscurecia a participação das vanguardas populares na pregação e os diferentes usos da categoria reformas de estrutura. As reformas de base seriam dirigidas "contra a revolução em marcha". Não havia possibilidade de realização das reformas nacionais e democráticas no regime democrático burguês instituído. Esse regime não tendia à democratização. "A cada avanço das forças do povo rumo ao poder, as classes dirigentes responderão com a crescente subtração das liberdades burguesas" (COSTA, 1962, p.82). O autor denuncia a entrada massiva de militares americanos no nordeste brasileiro, espiões disfarçados na figura de técnicos.

Além disso, argumenta que o imperialismo não permitiria à burguesia nacional se impor como classe dirigente única e absoluta. O dilema era liquidação ou associação com imperialismo. Como a burguesia brasileira nunca demonstrou capacidade de lutar contra imperialismo, não tem condições de manter governo próprio independente. "Têm de conformar-se com a sua condição de sócio, muitas vezes minoritário, do imperialismo, no processo de espoliação do povo" (COSTA, 1962, p.75). Com base neste diagnóstico, Costa cogitou a possibilidade de um golpe a ser desferido pelas forças conservadoras e políticas. Observava que o mecanismo da contrarrevolução brasileira estava articulado com o mecanismo do sistema contrarrevolucionário mundial. O imperialismo mantém a todo custo os países dependentes, tanto na América Latina, como na África e na Ásia. Os EUA elegiam as classes dirigentes das nações dependentes como forças contrarrevolucionárias, favoráveis à preservação de interesses externos.

Bolívar Costa tinha clareza da reação. Segundo ele, a Revolução Cubana retirou o elemento surpresa das revoluções latino-americanas, reduziu muito as possibilidades de surpreender as forças do imperialismo norte-americano. Este não iria mais permitir que as burguesias nativas se impusessem como classe dirigente única e absoluta. $\mathrm{O}$ antimperialismo da burguesia nacional era apenas a manifestação de um desejo inconsciente e reprimido de explorar com exclusividade os trabalhadores brasileiros. Conforme Costa (1962) a ação do imperialismo é

\footnotetext{
${ }^{12}$ Bolívar Costa (1928 - 1981), jornalista e escritor.
} 
coerente com os interesses a serem preservados. Pois, do contrário, estaria estimulando o ímpeto revolucionário das burguesias periféricas. Sob o risco de perder mercados, áreas anexas e lucros, o imperialismo norte-americano transferia capitais para o Brasil, controlava as empresas nacionais, deslocava fábricas inteiras para espaço econômico nacional. A indústria brasileira já não era mais nacional, constatava o autor.

Logo, não era do interesse dos EUA perder o Brasil, pois a revolução brasileira seria a viga mestra dos demais processos revolucionários na América Latina. O Brasil "é o campo em que se deverá travar a batalha decisiva com a contrarrevolução no hemisfério, o que confere às forças de esquerda de nosso país situação verdadeiramente singular no processo revolucionário do continente" (COSTA, 1962, p.60). Por conseguinte, as forças golpistas estavam muito articuladas e tinham grandes chances de sucesso.

Moniz Bandeira ${ }^{13}$ (1962) também exprime de forma nítida a consciência do golpe das classes dominantes. Ele questiona as reformas de base (proclamadas por uma parte da burguesia industrial, setores das classes médias que manipulavam, através de pelegos e burocratas, o movimento operário), as quais seriam defendidas para "evitar revolução e salvar o capitalismo". Critica o PCB por estar a reboque da burguesia e defende o caminho socialista para revolução brasileira, a ser alcançado por intermédio de um partido marxista-leninista capaz de reorganizar e unificar forças de esquerda. Necessidade de uma vanguarda para "conduzir e acelerar" a revolução brasileira. Autor se coloca contra a "acomodação reformista", "o direitismo da decrepitude" e contra o "aventureirismo de esquerda".

Inspirado no marxismo-leninismo elabora um diagnóstico no qual opõe reforma e revolução, afirma o caráter capitalista da economia brasileira à luz da lei do desenvolvimento desigual e combinado e do conceito de totalidade relacionado ao mercado mundial e advoga o sentido socialista da revolução brasileira. Operários e camponeses protagonizariam essa luta tanto pela via legal e parlamentar quanto pela via da insurreição defensiva, quando preparados por uma vanguarda, pois Moniz Bandeira previu o golpe burguês-militar. Em razão da crença em um iminente golpe, defendeu a insurreição preparada por uma vanguarda como resposta ao golpe a ser desferida pelos setores de esquerda das forças armadas. A ideia da insurreição defensiva

\footnotetext{
${ }^{13}$ Luiz Alberto de Vianna Moniz Bandeira (1935 - ) escritor, advogado, jornalista e militante socialista fez parte da elite política derrocada pela ditadura de 1964. Aos 20 anos de idade, fez campanha para JK na Bahia; aos 23 foi assessor do político nacionalista Sérgio Magalhães. Trabalhou com San Tiago Dantas, quando esse comprou o Jornal do Comércio. Filiado ao Partido Socialista Brasileiro, organizou, naquela época, a Juventude Socialista, no Rio de Janeiro, e na Bahia, estabelecendo contato com a Juventude Socialista de São Paulo. Defensor da fusão do Partido Socialista com o PTB (Partido Trabalhista Brasileiro). Foi um dos fundadores da Polop, organização brasileira de esquerda, fusão da Juventude Socialista com a Liga Socialista de São Paulo e a Mocidade Trabalhista de Minas Gerais. Após o golpe de 1964, rompe com a Polop, torna-se perseguido pela ditadura e engaja-se como escritor, publicando diversos livros.
} 
consistia em uma frente de soldados e sargentos, operários e camponeses dirigidos por uma vanguarda revolucionária, nos termos do marxismo-leninismo.

A história, porém, a despeito de permitir o conhecimento de suas tendências, é o terreno da luta de classes e das forças sociais, da indeterminação e do acaso na vida humana.

\section{Considerações Finais}

Com relação a esses projetos e essa esquerda brasileira em seu conjunto, podem ser interpretados também a partir da distinção proposta por Brandão (1999) entre esquerda positiva e esquerda negativa no interregno 1945-1964. A primeira, em meio à crise iniciada com a renúncia de Jânio Quadros, voltava atenção para a temática do desenvolvimento capitalista, para a tendência objetiva da democratização e para caminho pacífico para a revolução. Buscaria formar a vontade política através de metas realistas capazes de ampliar a organização popular, seguindo o princípio cartesiano de ir das questões mais fáceis às mais difíceis. Modo de fazer política que renega a concepção leninista de tomada do poder enquanto luta de uma só classe ou um só partido.

De acordo com Brandão (1999) a segunda alma, com a crise, defendia ampliação do mercado interno, realização de reforma agrária e rompimento com o capitalismo. A esquerda negativa tinha uma leitura catastrófica da crise econômica, nela havia predominância da questão nacional e insensibilidade para a questão institucional, mantinha uma visão confrontista que se atualizava com a Revolução Cubana. Voltava-se para objetivos gerais, abstratos e indeterminados, distantes da formação brasileira: "soviets", "governo operário-campônes", formação de um "exército de libertação nacional". Tal esquerda acreditava que as soluções positivas não seriam possíveis sob o capitalismo, restringindo-a a uma política de acumulação de forças. Tinha uma visão "salvacionista", uma concepção catastrófica das possibilidades internas de desenvolvimento capitalista, acreditava na militarização da política e na própria capacidade de fazer história.

Apesar disso, o golpe empresarial-militar não foi surpresa para alguns pensadores políticos das esquerdas brasileiras, tanto para a esquerda positiva quanto para esquerda negativa, como esse conjunto de autores analisados demonstra. Ao contrário, mais do que uma percepção, identificamos diferentes prognósticos acerca da possibilidade de derrota dos projetos de transformação social, por ocasião de um golpe de Estado contrarrevolucionário, protagonizado pelas classes dominantes, pelos militares e pelo imperialismo no Brasil. Portanto, para os pensadores das esquerdas brasileiras naqueles idos históricos, o golpe de 1964 não foi uma 
surpresa nem um raio em céu azul, mas significou a derrota e perseguição dos projetos que defendiam.

O argumento de responsabilizar a esquerda pela derrota de 1964 não se sustenta. Porque, mesmo se as esquerdas tivessem um diagnóstico correto da realidade, não é a racionalidade e conteúdo de verdade das ideias que comandam as decisões políticas, mas o jogo de forças políticas e sociais.

Nos momentos de crise torna-se mais evidente a importância da política para a modelação de uma política econômica entre as opções disponíveis. Na conexão entre crise econômica, debate político e experimentação política, não é a racionalidade dos diagnósticos, a verdade de uma teoria, que determina as escolhas políticas, mas o jogo de forças sociais. As decisões políticas dependem do apoio necessário das "coalizões históricas", dos atores sociais afetados pela crise, para que as medidas políticas adotadas sejam realizadas com vigor. Logo, a eficácia política das ideias não depende apenas de sua racionalidade e de sua coerência, mas do jogo político mais amplo, como ensina Gourevitch (1993).

Apesar destes vaticínios elaborados pelos pensadores políticos das esquerdas, a marcha golpista não foi detida e o Brasil mergulhou por mais de duas décadas na ditadura empresarialmilitar. As decisões políticas não são determinadas pela racionalidade do diagnóstico, mas pela disputa entre as forças sociais no âmbito da luta de classes. As forças liberais conservadoras tinham muito mais meios de ação e de divulgar suas concepções, visões e ideologias. Além disso, parece ter havido indiferença dos trabalhadores e de setores de esquerda nos sindicatos e nas forças armadas dos alertas feitos por esses intelectuais sobre a perspectiva de um golpe. Mas, aí já é outro problema a ser investigado. 


\section{Referências}

BASTOS, Élide Rugai. O outro Brasil de Luís Amaral. In: BOTELHO, A.; BASTOS, É. R.; VILLAS BOAS, G. (orgs.) O moderno em questão. A década de 1950 no Brasil. Rio de Janeiro: Toopbooks, 2008.

BRANDÃO, Gildo Marçal. A esquerda positiva. As duas almas do Partido Comunista (1920/1964). São Paulo: Editora Hucitec, 1999.

BANDEIRA, Luiz Alberto Moniz. O caminho da revolução brasileira. Rio de Janeiro: Editora Guanabara, 1962.

Trabalhismo e socialismo no Brasil. A internacional socialista e a América Latina. São Paulo: Global, 1985.

BEVIR, Mark. A lógica da história das ideias. Bauru: Edusc, 2008.

CARONE, Edgar. O PCB. Volume II. 1946-1964. São Paulo: Difel, 1982.

CHAUÍ, Marilena. O Nacional e o Popular na Cultura Brasileira - Seminários. São Paulo: Brasiliense, 1983.

CORTÊS, Norma. Esperança e democracia. As ideias de Álvaro Vieira Pinto. Belo Horizonte: Editora UFMG; Rio de Janeiro: IUPERJ, 2003.

COSTA, Bolívar. Quem pode fazer a revolução no Brasil? Cadernos do Povo Brasileiro. Rio de Janeiro, 1962.

DEBERT, Guita Grin. A política do significado no início dos anos 60: o nacionalismo no ISEB e na ESG. Tese em Ciências Sociais. São Paulo: USP/FFLCH, 1986.

DREIFUSS, RENÉ. 1964. A conquista do Estado: ação politica, poder e golpe de classe. Petrópolis: Vozes, 1981.

FRANCO, Maria Sylvia Carvalho. O tempo das ilusões. In: ; CHAUÍ, M. Ideologia e mobilização popular. Rio de Janeiro: CEDEC/Paz e Terra, 1978.

FERREIRA, Jorge. Entre a história e a memória: João Goulart. In: ; REIS, D. A. Nacionalismo e reformismo radical. 1945-1964. Rio de Janeiro: Civilização Brasileira, 2007.

FURTADO, Celso. A pré-revolução brasileira. Rio de Janeiro: Editora Fundo de Cultura, 1962.

GARCIA, Marco Aurélio. As esquerdas no Brasil e o conceito de revolução: trajetórias. In: ARAÚLO, A. M. C. Trabalho, cultura e cidadania: um balanço da história social brasileira. São Paulo: Scritta, 1997. 
GOUREVITCH, Peter. Políticas estratégicas em tempos dificiles. Respuestas comparativas a lascrisis econômicas internacionales. México: Fondo de cultura econômica, 1993.

IANNI, Octávio. O ciclo da revolução burguesa. Petrópolis: Editora Vozes, 1984.

MELO, Demian Bezerra de; HOEVELER, Rejane Carolina. Muito além da conspiração: uma reavaliação. Crítica da obra de René Dreifuss. Tempos Históricos. v. $18,2014$.

MIGLIOLI, Jorge. O ISEB e a encruzilhada nacional. In: TOLEDO, C. N. (org.). Intelectuais e política no Brasil. A experiência do ISEB. Rio de Janeiro: Revan, 2005.

MORAES, Denis de. A esquerda e o golpe de 64. 2 ed. Rio de Janeiro: Espaço e Tempo, 1989.

MORAES, João Quartim. A esquerda militar no Brasil. Da conspiração republicana à guerrilha dos tenentes. 2. ed. São Paulo: Expressão Popular, 2005.

MORAIS, Pessoa. Sociologia da revolução brasileira: análise e interpretação do Brasil de hoje. Rio de Janeiro: Leitura, 1965.

NAPOLITANO, Marcos. Forjando a revolução, remodelando o mercado: a arte engajada no Brasil (1956-1968). In: FERREIRA, J.; REIS, D. A. Nacionalismo e reformismo radical. 1945-1964. Rio de Janeiro: Civilização brasileira, 2007

OLIVEIRA, Francisco. A economia brasileira: crítica à razão dualista. Estudos Cebrap, São Paulo, n. 2, 1972.

OLIVEIRA, Franklin de. Revolução e contra-revolução no Brasil. Rio de Janeiro: Civilização Brasileira, 1962.

PINTO, Álvaro Vieira. Consciência e realidade nacional. Livro I: A consciência ingênua. Rio de Janeiro: Instituto Superior de Estudos Brasileiros, 1960.

Consciência e realidade nacional. Livro II: A consciência crítica. Rio de Janeiro: Instituto Superior de Estudos Brasileiros, 1960.

RAMOS, Guerreiro. A crise do poder no Brasil: problemas da revolução nacional brasileira. Rio de Janeiro: Zahar Editores, 1961.

1963.

Mito e verdade sobre a revolução brasileira. Rio de Janeiro: Zahar Editores,

REIS FILHO, Daniel Aarão. A revolução faltou ao encontro. São Paulo: Brasiliense, 1990.

Um balanço da historiografia sobre a esquerda brasileira. In: ARAUJO, A. M. C. Trabalho, cultura e cidadania: um balanço da história social brasileira. São Paulo: Scritta, 1997. 
RIDENTI, Marcelo. O fantasma da revolução brasileira. São Paulo: Unesp, 1993.

SEGATTO, José Antônio. PCB: a questão nacional e a democracia. In: FERREIRA, J.; DELGADO, L. de A. N. (orgs). O Brasil republicano. O tempo da experiência democrática. Rio de Janeiro: Civilização Brasileira, 2008.

SANTOS, Wanderley Guilherme dos. Quem dará o golpe no Brasil? Cadernos do Povo Brasileiro. Rio de Janeiro: Civilização Brasileira, 1962.

SODRÉ, Nelson Werneck. Quem é o povo no Brasil? Cadernos do Povo Brasileiro. Rio de Janeiro: Civilização Brasileira, 1962.

A ofensiva reacionária. Rio de Janeiro: Editora Bertrand Brasil, 1992.

TÁVVORA, Juarez. Á guisa de depoimento sobre a revolução brasileira de 1924 - 2 vol. São Paulo: O combate, 1928.

TOLEDO, Caio Navarro. As falácias do revisionismo; Sobre Golpe de 1964. Crítica Marxista, n.19, 2004.

ISEB: fabrica de ideologias. São Paulo: Ática, 1977.

VIOTTI DA COSTA, Emília. A Revolução Burguesa no Brasil. In: FÉLIX, M. (org.). Encontros com a Civilização Brasileira. Rio de Janeiro, Civilização Brasileira: 1978. 